УДК 398.8:392.51(497.7)(049.3)

УДК 39:316.323.6(497)(049.3)

https://doi.org/10.55302/MF2077-78165d

Александар Димитријевски

\title{
МЕЃУ ТРАДИЦИОНАЛНОТО И СОВРЕМЕНОТО: ТРАНСФОРМАЦИЈАТА НА РЕПЕРТОАРОТ НА МАКЕДОНСКИТЕ СВАДБЕНИ ОБИЧАИ
}

Апстракт: Свадбените обичаи се меѓу најистакнатите и најзачуваните од сите македонски обичаи. Тие се богати со сегменти што вклучуваат разновидни музички жанрови како извор на интерпретација или едноставно како музичка заднина.

Генерално, се забележува дека постојат значајни разлики меѓу традиционалната и современата форма на македонски свадбени обичаи. Уште повеќе, современата форма покажува прифаќње на нови обичаи и отфрлање на некои од старите. Како резултат на тоа, музичкиот репертоар претрпел значителна трансформација.

Во тој контекст, овој труд се фокусира на специфичниот случај на промени меѓу традиционалните и современите македонски свадбени обичаи и особено на промените во музичкиот репертоар. Во овој труд ќе се обидам да ги детерминирам основните сегменти и промените на споменатите свадбени обичаи, а особено степенот на трансформација на музичкиот репертоар.

Клучни зборови: македонски музички фолклор, традиционални свадбени обичаи, современи обичаи, свадбен репертоар.

Создавањето на овој труд е поттикнато од мојот интерес кон истражувањето на современиот наспроти обредно-обичајниот свадбен репертоар.

Но, генерално, разбирањето и анализата на музиката во современите македонски свадбени обичаи не може да се изведе без познавање на традиционалниот македонски свадбен циклус и следствено, на позицијата на музиката во него. Во оваа функција беше и прегледот на трудовите и другите артефакти, кои се однесуваат на оваа проблематика. Сепак, заради градење таксономија, која натаму ќе ја користам како основа и ориентир, се одлучив да се осврнам, односно да ги сумирам претходните сознанија за општата структура на традиционалниот свадбен циклус и да ја поткрепам со примери од своето лично искуство, кои во целост ги следат традиционалните свадбени обичаи.

Во оваа смисла ќе ги искористам класификациите, кои сметам дека се најблиску до моето сфаќањ на структурата на традиционалниот свадбен циклус. Така, најнапред би ја навел класификацијата на Весна Петреска, од нејзината докторска дисертација (Петреска, 2002) во која свадбениот циклус 
содржи четири фази: претсвадбени обичаи, подготовки за свадба, свадбени обичаи и постсвадбени обичаи.

Слична поделба, употребена во контекст на свадбените песни, се среќава и кај Кирил Пенушлиски во студијата за малешевскиот фолклор. Тој вели: „Точно е определено кога, каде и од кого се пеат одделни песни. Тие не се само интегрален дел од обичаите на обредите, туку и нивно осмислување. Можат да се поделат на три групи: претсвадбени, свадбени и посвадбени... “ (Пенушлиски, 2003, 511).

Очигледно е дека кај овие примери се јавува варирање меѓу три и четири општи фази.

Една подетаљна класификација на сите елементи на свадбениот циклус има изработено Татјана Жежељ-Каличанин, која, сепак, го дели во четири фази:

- свршувачка, строј, армас и подготовки за свадбата;

- денот на свадбата;

- заеднички обреди;

- посвадбени обреди.

(Жежељ-Каличанин, 2008).

Жежељ-Каличанин, исто така, ја истакнува и варијантноста на посочените обичаи и обреди: „... При анализирањето на свадбените обреди на целата територија на Македонија, секогаш се имаат предвид и многубројните варијанти што се карактеристични за секој регион, како во редоследот на обредните дејства, така и во бројот, кои во различните средини можат да бидат проширени или редуцирани со намален број, или да се прелеваат или спојуваат еден во друг... “(Жежељ-Каличанин, 2008, 10).

Четирите основни фази на свадбените обичаи се само генерализација, која во практиката раѓа безброј регионални, локални, па и индивидуални варијанти. Од своја страна, тие можат да доживеат и одредена стандардизација преку обид да се петрифицираат обичаите - преку современи манифестации, како во случајот со познатата Галичка свадба од Западна Македонија, која, како посебен културен феномен, веќе резултира со слични обиди и во други делови од Република Македонија.

Затоа, во овој труд имам за цел да ги илустрирам и да ги пренесам во практичен пример сознанијата за фазите на традиционалниот свадбен циклус и нивната трансформација во современиот свадбен циклус преку обработката на свадбените обичаи и песните што ги придружуваат.

\section{Традиционален свадбен циклус}

Овде ќе издвојам некои сознанија, кои ќе ги опеарационализираат погоре наведените класификации и ке ги поткрепат со музички примери. 
Претсвадбени обичаи

Стројник, строј и свршувачка

Претсвадбените обичаи, кои воопшто не вклучувале или малку вклучувале музика во целост, ги отсликуваат релациите што, во минатото, постоеле во семејството и во социјално-културното опкружување (одлуките на постарите, позицијата на младите, позицијата на жената, предбрачната врска меѓу младите итн.). Овие обичаи биле неминовен дел од свадбениот циклус и во одредена мера се присутни до денес преку „свршувачката“ или „давање збор“ (опис на претсвадбените обичаи дава и Мирјана Мирчевска во својот труд за свадбените обичаи од с. Подгорци, Струшко, каде што во овој комплекс обичаи го вклучува и обичајот давање збор (Мирчевска, 1993).

\section{Подготовки за свадба}

Завивање на вениите, месење на погачата, одење по невестата

Во областа Скопска Блатија во минатото подготовките за свадбата започнувале уште во среда. Тогаш се „завивале венците“. Наредниот ден, во четвртокот, се „месела погачата“. Во петокот се подготвувале за веселбата во наредните денови. Саботата била ден за „одење по невестата“.

\section{Свадбени обичаи}

Забричување на младоженеиот, доаѓање на невестата во домот на младоженецот

Неделата била ден за венчавката и главната веселба во домот на младоженецот. Овој ден содржи и повеќе други придружни обичаи во зависност од регионот во кој се изведува свадбата. Прв од обичаите, придружен со обредни песни, во неделата, е забричување (бричење) на младоженецот. Откако младоженецот е избричен, во неговиот дом доаѓаат сватовите со невестата. Кога невестата влегува во дворот ги дарува свекорот и свекрвата, а притоа се изведуваат обредни песни. По изведувањето на овој обичај се оди во црква на венчавање. По венчавањето продолжува веселбата во домот на младоженецот.

\section{Постсвадбени обичаи}

Во понеделникот во домот на младоженецот се одвива интересен обичај, кој се нарекува блага ракија. При овој обичај според кажувањата на информаторите не се изведуваат обредно-обичајни песни, но е карактеристично тоа што е ова „ден кога се веселат жените“. 
Во текот на наредните неколку недели новите сватови си оделе на „првиче“ - денот кога новите сватови за првпат ке си одат на гости, на ручек или на вечера, едни кај други.

Детаљниот опис на традиционалниот свадбен циклус го обработив и го презентирав во своите претходни истражувања (Димитријевски, 2014).

\section{Современ свадбен циклус}

Освртот кон современите свадбени обичаи е во центарот на основниот научен интерес на овој труд - трансформацијата на музичкиот репертоар кај свадбените обичаи.

Атрибутот „современи“ треба генерално да упати на свадбените обичаи во Република Македонија во 21 век. Имајќи предвид дека, всушност, не постои изразена граница меѓу „традиционалното“ и „современото“, посебно што може да се забележи дека денес подеднакво егзистираат и целосно традиционални примери како Галичката свадба. Сепак, главната разлика, е изведена врз основа на временската рамка. Меѓутоа, „тивката трансформација“, односно еволуцијата што се случува во фолклорот и во современата музичка традиција, сепак постепено воведува разлики што произлегуваат од промените на опкружувањето, што особено драстично се случија во нашето време. Натрупувањето на овие промени во некои сегменти на свадбениот циклус ќе му дадат комплетно нов, односно многу поразличен формат од минатото.

Наспроти отсуството на теориски трудови, посветени на оваа проблематика, постојат мноштво материјали во печатените и во електронските медиуми.

Во печатените медиуми многу често се среќаваат написи за свадби на познати личности од естрадата и општествено-политичкиот живот. Во нив е презентирано преплетувањето на старите и на поновите, македонските и интернационалните свадбени обичаи, и поради популарноста на младоженците, стануваат модел за имитација.

Во електронските медиуми, исто така, сретнав примери на радио и ТВемисии, кои се занимаваат со приказ на свадбите на познатите личности кај нас.

Моделите за наведениот тип емисии, меѓу другото, се црпат од многубројните странски интернет-страници, кои се појавија во последните децении и кои се посветени на планирањето на свадбите.

Исто така, на овие сајтови постои детаљно објаснување на целосниот музички репертоар, потребен за секој сегмент од современите свадби.

Битна карактеристика на современите свадбени обичаи е и задолжителното снимање на визуелни носачи.

Всушност, во последните неколку децении постепено се воведуваше користењето на фотоапарати, филмски и потоа електронски аналогни камери (VHS), и во последната декада - масовна употреба на дигитални камери, со кои се регистрира целиот настан. Овој процес го следеше и користењето на 
професионални фотографи, и потоа никнувањето многубројни студија за (аналогно, а подоцна и дигитално) видеорегистрирање на свадбите.

Претставувањето на денешните фази на свадбениот циклус го изведов според податоците собрани од своите истражувања.

За разлика од традиционалната форма на свадбата, која, како што видовме, траела повеќе денови и опфаќала повеќе обреди и обичаи, современата форма се одвива во рамките на два дена од еден викенд. Таа ги содржи следните сегменти:

$$
\begin{array}{ll}
\text { - } & \text { подготовки; } \\
\text { - } & \text { одење по невеста; } \\
\text { - } & \text { регистрација во матично; } \\
\text { - } & \text { венчавање во црква; } \\
\text { - } & \text { веселба во ресторан; } \\
\text { - } & \text { понеделник или блага ракија } .
\end{array}
$$

Со оглед на комплексноста на самиот истражуван феномен на кој, како што споменав, може да му се пристапи од најразлични содржински и методолошки агли, мојот интерес беше фокусиран врз анализата на изведуваниот репертоар. На овој начин се добија сознанија и за неговата функционалност во различните фази на свадбените обичаи и за неговата содржинска и формална музичка структура.

\section{Анализа на музичкиот репертоар во современите македонски свадбени обичаи}

Репертоарот на современиот свадбен циклус генерално е составен од два дела:

- песни и ора со посебна намена, кои се задолжителен дел од секој свадбен циклус и не се менуваат;

- песни и ора без посебна намена, кои се изведуваат при временски подолгите фази од свадбениот циклус (одење по невеста, свадбена веселба во ресторан/дома и сл).

Репертоарот со посебна намена е неменлив дел од музичката изведба на секоја свадба и содржи точно определени музички дела за секој од обичаите од фазите на свадбениот циклус, додека другиот дел од репертоарот, односно оној дел без посебна намена има исклучиво функција на забава за свадбените гости и е предодреден за личните музички вкусови на сватовите или на самите изведувачи. Тој дел од репертоарот е, исто така, универзално креиран за повеќе типови веселби, покрај за свадбите, и за: крштевки, родендени, прослави на матури, Нови години и празници.

Со оглед на тоа што во првата фаза не се изведуваат обичаи придружени со музика, ќе започнам со втората фаза. 


\section{Втора фаза - „одење по невеста“}

Во фазата „одење по невестата“ (значи дека младоженецот со своите сватови оди „да ги земе“ невестата и нејзините сватови од нејзиниот дом и заедно се упатуваат кон црквата на венчавање) е вклучен помал свадбен музички состав, најчесто трио или квартет.

Веселбата во домот на младоженецот започнува со песната „Домаќине, добри гости ти дојдоа“ (најчесто посветена на таткото на младоженецот, идниот свекор), па потоа му се пее на младоженецот „Ерген одев, мајко“.

Кумот се пречекува со песната „Еј, море, куме златен“. На оваа песна кумот го заигрува првото оро што му е посветено нему. Откако ќе се заврши песната, кумот седнува „на чело“ на свадбената маса.

По завршувањето на свадбената веселба во домот на младоженецот, сватовите се упатуваат кон домот на невестата. На излегување од домот, пред куќата, играат три ора. Првото го поведува свекрвата држејќи ја погачата („сваќата“), која ќе ја кршат идните сватови во домот на невестата.

При влегувањето во домот на невестата се пее песната „Врана коња јавам јас“". Откако сватовите ќе влезат во домот, музичката група повторно ја изведува песната „Домаќине, добри гости ти дојдо““.

Изведувањето (излегувањето) на невестата пред сватовите е проследено со песната „Марие, млада невесто“.

Веселбата продолжува и се изведуваат песните „Зете, мили зете“, „Ах, мори бабо“, „Доста време ерген одев“, „Четири месеци свадба се спрема“, „Свирете ми свирачи“" наменети за младоженците и нивните семејства, а потоа се изведуваат други песни, кои немаат директна функција, освен за забава на сватовите. По неколку часа сватовите излегуваат од домот со песната „Черешна се од корен корнеше“ и пред куќата играат три ора.

Во последниве години сѐ позабележлива е појавата одреден број невести да не се согласуваат, на нивната свадба, да биде изведена посочената песна „Черешна се од корен корнеше“. Причината е во тоа што тажните чувства при „разделбата“ од родниот дом уште повеќе се потенцираат преку оваа песна или, според зборовите на одреден број невести: „...Таа песна ме тера да плачам...“. За таа цел музичарите имаат измислено опција со која, обичајот сепак да се изведе, но со слична песна, која не буди исти чувства кај невестите. Станува збор за песната „Илчовице, млада невесто“, која често се изведува на свадбените веселби поради почетниот стих, иако песната е љубовна и нема свадбена содржина.

Добиените резултати потврдуваат дека постои изразена застапеност на македонската народна музика и многу мала разновидност на жанрови во оваа фаза. Ова ја потврдува констатацијата дека оваа фаза е остаток од традиционалната форма на свадбениот циклус. Оттаму и музиката, која се изведува во оваа фаза, освен во исклучоци, го задржува принципот на изразување на „националното обележје“ преку изведбата на македонска национална музика. 


\section{Трета фаза - „матично“}

Во описот на структурата на современиот свадбен циклус веќе посочив дека музиката во оваа фаза од свадбата постои само при доаѓањето во општинската установа или по завршувањето на регистрацијата на пат кон црквата. Евидентно е дека во оваа фаза се појавуваат исклучиво музички единици со потекло од македонската народна и етнопоп-музика.

\section{Четврта фаза - „црква““}

Црковната свадбена церемонија содржи обреди и духовни песни, кои имаат за цел да ги спојат младоженците во света заедница. Црковното пеење претставува единствена врска со духовната култура и со обредноста на современата свадба. Со оглед на тоа што црковната музика наменета за венчавање не е во сферата на мојот интерес, тој дел ќе го изоставам од анализата. Во истражувањето се вклучени само оние музички единици изведени пред и по црковната церемонија, а кои се доминантно македонска народна и македонска етнопоп-музика.

\section{Петта фаза - „веселба во ресторан“}

Оваа фаза започнува со т.н. „отворање на веселбата“, односно музика за пречек на гостите. Во овој дел од веселбата оркестарот најчесто изведува евергрин-музика, односно музика од странско потекло.

Влегувањето на младоженците е придружено со „свадбен марш“ (најчесто тоа е музиката од „Свадбениот марш“ од Ф. Менделсон).

По наздравувањето, следува првиот танц (во минатото најчесто валцер, а во последните децении - пример од забавна музика). Оркестарот ги најавува младоженците и ги поканува да заиграат и со тоа, да ја започнат веселбата. Набргу потоа во танцувањето се придружуваат и другите гости. Од тој момент веселбата е започната официјално. Потоа, оркестарот започнува редоследно да изведува по една песна (или поретко оро) наменети за: невестата, младоженецот, кумот, старосватот (старосватицата), свекорот, свекрвата, дедото, бабата и деверот. Редоследно ќе ги наведам најчесто изведуваните песни со посебна функционална намена:

- за невестата „Марие, млада невесто“ или „Илчовице, млада невесто“ (поретко „Невестинско оро“);

- за младоженецот „Ерген одев мајко“ или „Доста време ерген одев“;

-за кумот „Еј, море, куме златен“;

- за старосватот (почесто старосватицата) „Стани моме да заиграш“;

- за свекорот „Свирете ми свирачи“;

- за свекрвата „Ти донесов млада невеста“;

- за дедото „Дедо мили, златни“;

- за бабата „Ах, мори, бабо“ или „Зете, мили зете“;

-за деверот „Свадба македонска“ или „Ах, да беше стрела песнава“. 
Кога ќе се завршат сите песни со намена, оркестарот изведува музика според однапред договорена програма или пак, според изборот на гостите.

Во одреден дел од веселбата оркестарот, во зависност од желбата на гостите, покрај народни и етнопоп-песни и ора, изведува и поинаков репертоар: песни од поп и рок-музика.

За подобрите игроорци, во текот на веселбата, речиси редовно се изведуваат и најпопуларните македонски ора: „Пајдушкото оро“ во 5/16 (23), „Елено моме“ во 7/8 (223), „Циганчица“ во 7/16 (223), „Двојка“ (или „Чачак“) во 2/4 (во триоли како 6/8), „Тројка““ во 4/4 итн.

До крајот на веселбата се случуваат и сечењето на тортата и фрлањето на бидермаерот (букетот), со кои се означува и крајот на веселбата. Овие обичаи се најчесто придружени со инструментален „џингл““. Откако бидермаерот ќе биде „фатен“, оркестарот изведува една ороводна музичка нумера на која орото го поведува онаа девојка (или момче), која го фатил/а букетот. Многу често поради симболиката на желбата на онаа која го фатила букетот да стане идна невеста (односно младоженец) музичкиот состав изведува (една од најпознатите и најизведуваните варијанти на) „Невестинско оро“.

Во оваа фаза постои употреба на најголем број жанрови, за разлика од другите фази, во кои првенствено доминира употребата на македонската народна музика. Но, и покрај големата употреба на различните жанрови, сепак, и во ова вкрстување, резултатите покажуваат дека најголемиот дел од изведбите ѝ припаѓаат на македонска народна музика. Затоа, ова вкрстување е уште една потврда не само за преференцијата на македонската популација, која спонтано, на тој начин, го изразува и својот идентитет, туку и за континуитетот во одржувањето на традицијата. Ова уште повеќе доаѓа до израз во примерот на Галичката свадба и интересот што, во последниве децении, се пројавува за се́ поголемо реконструирање на автентичните регионални традиции.

\section{Шеста фаза - ,понеделник“6 и ,блага ракија“}

Во понеделникот, односно ден по венчавката се прави т.н. „блага ракија“ (веселба на која се приготвува загреан алкохол со карамелизиран шеќер). На оваа веселба порано, во повеќе краишта на Македонија, се собирале и се веселеле единствено жените. Исто така, оваа веселба е позната по тоа што жените во минатото пееле песни со еротска содржина, која е поврзана со плодноста на младоженците.

Современите свадбени циклуси, кои ги истражив јас, покажаа дека таквата содржина на овој обичај веќе не се практикува. Наместо тоа на „благата ракија“ се собираат и машки и женски гости, а веселбата има вообичаен тек како и веселбите во претходните фази. Притоа, може да биде најмена помала музичка група од типот свадбарско дуо или свадбарско трио. Репертоарот со посебна намена што се изведува во оваа фаза е претставен преку примерот „Ожени ме, мамо“. Сепак, ангажирањето на музичка група за 
веселбата во оваа фаза сѐ поретко се случува. Наместо тоа, веселбата поминува без т.н. „жива музика“, односно изведба од музичка група.

\section{Заклучок}

Традиционалниот свадбен циклус содржи сегменти од сите четири фази наведени во општата класификација: претсвадбени обичаи, подготовки за свадба, свадбени обичаи и постсвадбени обичаи.

Традиционалниот свадбен циклус претставува уникатен и типичен пример на дел од традицијата, која е зачувана и до денес, во сеќавањата на повозрасните информатори.

Во однос на современиот свадбен циклкус, обработката на дигитализираниот корпус недвосмислено укажа на присуството на големиот број музички елементи преземени од традиционалните форми, односно формите од минатото, и нивната трансформација, односно адаптација, во современото опкружување во Република Македонија.

Со тоа, современите свадбени обичаи се во континуитет со традицијата и покрај огромните промени, кои, во меѓувреме, се настанати во музичката култура на регионот. Свадбените обичаи остануваат енклава во која автохтоната музичка култура се спротивставува на хомогенизацијата што ја следи светската музичка култура.

\section{ЛИТЕРАТУРА}

ДИМИТРИЈЕВСКИ, А. (2014). Музиката во македонските свадбени обичаи во 21 век. Скопје.

ЖЕЖЕЉ-КАЛИЧАНИН, Т. (2008). Македонски свадбени обичаи и песни. Скопје.

МИРЧЕВСКА, М. (1993). Свадбените обичаи кај Македонците во селото Подгорци-Струшко. Етнолог, год. II, бр.3, 145-150. Скопје.

ПЕНУШЛИСКИ, К. (2003). Македонски фолклор, студии и прилози. Скопје.

ПЕТРЕСКА, В. (2002). Свадбата како обред на премин кај Македонџите од брсјачката етнографска ичелина. Скопје.

Aleksandar Dimitrijevski

\section{BETWEEN THE TRADITIONAL AND THE CONTEMPORARY: THE TRANSFORMATION OF THE REPERTOIRE IN MACEDONIAN WEDDING CUSTOMS}

\section{Summary}

The main interest in this paper is the music repertoire in Macedonian wedding customs. In general, I noticed existance of two forms of the Macedonian wedding customs: traditional and contemporary form. It is noticeable that there are significant differences between the traditional and the contemporary form. Even more, the contemporary form shows the acceptance of new customs and rejection of some of the old ones. As a result, the 
music repertoire suffered significant transformation. In this context, this paper focuses on the specific case of changes between the traditional form and the contemporary form of the Macedonian wedding customs and especially the level of transformation of the music repertoire. 